\title{
The spark in the engine:
}

\section{creative workers in a global economy}

\author{
Ursula Huws \\ Ursula Huws is professor of international labour studies at the \\ Working Lives Research Institute at London Metropolitan Univer- \\ sity, UK, the director of Analytica and the editor of this volume.
}

\begin{abstract}
Introducing this volume, this paper summarises the contents and offers an analysis of the place of creative work in a global economy, focusing in particular on the restructuring of global value chains and the commodification of knowledge in a process which simultaneously opens up the possibility for new creative tasks for some workers whilst deskilling others. It concludes with a discussion of the contradictions that this presents for creative workers who may be offered a choice between disappointing their own creative aspirations or collaborating in their own exploitation.
\end{abstract}

\section{Introduction}

There are few greater pleasures in life than the satisfaction that comes from making something original and beautiful, whether this is a musical performance, a crafted object or the solution to an intellectual puzzle.

One of the most famous celebrations of the joy of creative work is by William Morris whose utopian 1890 News from Nowhere was set in a future time in which: 'all work is now pleasureable; either because of the hope of gain in honour and wealth with which the work is done, which causes pleasurable habit, as in the case with what you may call mechanical work; and lastly (and most of our work is of this kind) because there is conscious sensuous pleasure in the work itself; it is done, that is, by artists.'(Morris, 1890)

This 'conscious sensuous pleasure in the work itself' isn't limited to artists. Studs Terkel, in his remarkable 1974 collection of interviews with people about their work, elicited descriptions of it across an astonishingly broad spectrum of tasks and occupations.

Here for instance is a book restorer:

'l'm just a swabber...l'm not an artist...It isn't very skilled work...It's just knowing what books need, if you want to preserve them. It's just something you do... A mechanic takes care of a tire and he knows... But if you bind good books, you make something really good, really and truly good.' (Turkel, 1974:268)

And a hairdresser:

'Once in a while a hairdo will disturb me because I feel I didn't do it quite right. I'll brood over it for a little while. I like to feel l've done the best on each one each day.' (ibid:217) 
And a housewife:

'I'll sit here and I'll bake a pie and I'll get to see everybody eat it. This is my offering.

I think it's the greatest satisfaction in the world to know you've pleased somebody.' (ibid:258)

Some poetry can be generated from even the most apparently boring and pressurised labour processes. Here, is a supermarket checkout operator:

'I use my three fingers - my thumb, my index finger and my middle finger. The right hand. And my left hand is on the groceries ... I got my hips pushin' on the button and it rolls around on the counter. When I feel I have enough groceries in front of me, I let go of my hip. I'm just movin' - the hips, the hand, and the register, the hips, the hand and the register...If you've got that rhythm you're a fast checker...If somebody interrupts to ask me the price, I'll answer while I'm movin'. Like playin' a piano.' (ibid:241-2)

Perhaps because of some dogged refusal to believe that the long hours spent labouring could be entirely futile, and the amazing human ability to extract meaning and pleasure from any daily experience, there is a sense in which nearly all work can be experienced as creative, at least some of the time.

When most people these days speak of creative work, however, they have a somewhat narrower range of tasks in mind - typically those that involve 'having ideas' for new products or processes, adapting existing ones for new purposes or creating content for the mass media. Richard Barbrook (2006) has comprehensively catalogued the many collective nouns that have been coined to describe these workers. The 70-odd terms he lists include Helen Wilkinson's (1999) 'elancers', David Brooks' (2000) 'bobos' ('bourgeois bohemians'), Franco Bifo Berardi's (2001) 'cognitariat', and John Brockman's (1996) 'digerati' as well as Richard Florida's (2002) rather better known 'creative class'. William Morris, incidentally, preferred the term 'intellectual proletariat' to refer to creative workers (Morris, 1886).

Why the urge to classify these workers? And why, particularly, now? With the simultaneous spread of digital technologies and globalisation of trade in the last years of the $20^{\text {th }}$ century they have assumed a new importance as sources of 'added value' or 'intellectual property' (IP). In the 'knowledge-based economy' that public policies increasingly aspire to $^{2}$, creativity is regarded as the essential raw ingredient of economic growth.

If, as the European Council put it in its famous 2000 Lisbon Declaration, 'The shift to a digital, knowledge-based economy, prompted by new goods and services, will be a powerful engine for growth, competitiveness and jobs.' (Lisbon European Council, 2000:1)

then creative workers are the spark in this engine.

Whilst regions and cities compete to attract creative industries (Ross, this volume), corporations carry out 'knowledge audits' (Bontis, 2001, Sveiby, 1997), measure their 'intellectual capital' (Edvinsson \& Malone, 1997), rate how their employees perform on

$1 \quad$ All dates and citations here are from Barbrook (2006)

2 See, for instance, the European Union's official adoption, at the 2000 Lisbon Summit, of the 'strategic goal for the next decade: to become the most competitive and dynamic knowledge-based economy in the world' (Lisbon European Council, 2000:1) 
the MBTI-Creativity Index (Weiner, 1990), pour resources into 'knowledge management' (Tiwana, 2002) and ensure that their employees' ideas are copyrighted and patented, whilst the World Trade Organisation acts as a global police force to protect this newly appropriated 'knowledge'.

Creative workers would appear to be in demand as never before, but their creativity is also subject to control and contestation as never before.

\section{Contents of this volume}

This volume takes these creative workers for it subject. First, Andrew Ross sets the scene with an account of the 'mercurial career of creative industries policies' illustrated by the examples of the UK, the USA and China. One of the most influential shapers of these policies has been Richard Florida, whose consultancy services have contributed to the development of many of them. His central thesis - that creating 'cool cities' will attract creative talent which will in turn generate economic growth - is challenged in the next paper by Richard Shearmur, who draws on a detailed analysis of urban growth and graduate migration in Canada to demonstrate that the reality seems to be exactly the opposite: graduates move to where the economic growth is taking place, not vice versa.

Next, we have a series of empirical accounts of the working lives of the creative workers these policies seek to attract. Sybille Reidl, Helene Schiffbänker and Hubert Eichmann present a study of creative workers in Vienna which paints a picture of people who clearly enjoy their work, but unless they are lucky enough to work for the well unionised national broadcasting authority or in a highly regulated profession like architecture, pay a high price for this in long hours, precariousness and stress that reaches out into their personal lives. This theme is picked up by Bettina-Johanna Krings in a qualitative study that looks into what being a creative worker means for women in Germany who have, within a generation, moved from a typically home- and family-centred model of life to a work-centred 'breadwinner' model. The different strategies adopted to cope with this change range from giving up the idea of motherhood altogether to living in a permanent state of stress from the effort of juggling the demands of work and daily life. Ashika Thanki and Steve Jefferys describe the informalised labour market of the media industries in London and show how the need for personal contacts to find work and the precariousness of the workforce have reinforced the dominance of the industry by a white middle-class elite, serving not only to marginalise Black and minority ethnic workers in the workforce but also to perpetuate racism in programme content.

Bob Hughes places the concept of the 'creative' in a historical context, describing its evolution into an instrument of management control, drawing on his own experience in the advertising industry in the 1970s and 1980s to show how the division of the workforce into 'suits' and 'creatives' served to infantilise the 'creatives' and alienate them from craft-based trade unionism as well as from progression to positions of authority.

In a study of the values of new media workers in Madrid, Armando Fernández Steinko also takes up the issue of infantilisation, placing it in the context of traditional forms of organic solidarity that exist in Southern Europe. Because of the precariousness of the new economy labour market, the young workers in his study 
are still likely to be living with their parents well into their thirties and transfer their unquestioning attitudes to authority from the extended family to the small firms for which they typically work, and he explores the implications of this for their ability to develop a critical perspective on their work and on the world in general.

A paper by Simone Dahlmann and Ursula Huws illustrates the impact of offshore outsourcing of editorial work from the UK to India, describing the shock experienced by the British workers when they discovered that the skills in which they took pride were so easily replaceable, and the stress and insecurity experienced by the new Indian workforce as a result of having to meet the company's demands for 'flexibility'.

Finally, two papers explore workers' organised resistance to the precarisation of their jobs and the restructuring of the industries that employ them. Catherine McKercher and Vincent Mosco examine how the culture and sense of craft identity of their members led to a failure of two Hollywood trade unions to unite, despite overlapping membership, technological convergence between different media and mergers between the employers with whom they negotiate. Leif Schumacher looks at the video games industry, where workers in California have taken class action suits against their employers to win the right to overtime pay. Ironically in order to do so they had to argue that their work was not 'creative' because it involved working to tight supervision under conditions that bore more resemblances to a Fordist assembly-line than to the unstructured autonomous working conditions described in many accounts of the new economy. These Taylorised working conditions, he argues, cast doubt on the hypotheses that new autonomous forms of work are emerging and that what Marxist autonomists (Hardt and Negri, 2000) call the 'multitude' of 'immaterial workers' will adopt quite different forms of resistance from their 20th century forerunners.

Taken together, these accounts paint a highly contradictory picture. Across the world, motivated no doubt in part by the 'cool' of the new economy and media industries, and the enticing promise of autonomy, self-expression and social prestige, young people in large numbers seek out creative work even when they know that, compared with other kinds of work, it is precarious, competitive and may well involve long hours and poor rewards, and that the odds against achieving individual stardom are overwhelming. They are often prepared to pay a high price for this - prolonged economic dependence on parents or partners, a constrained social life, and no guarantee of long-term security, pension rights, paid holidays or the kind of slack that makes it possible to deal with unforeseen developments in their private lives.

Why are they so willing to strike this unequal bargain? and what happens when their desire for creative fulfilment, or Morris's 'conscious sensuous pleasure in the work itself' collides head-on with the employer's need to cut costs and standardise processes?

I will return briefly to these questions at the end of this paper. But first, I will present a more structural account of the role played by creative work in thecommodification process in the hope that this will shed some light on these contradictions.

\section{The place of creative work in the commodification process}

Two things lie at the source of every commodity: natural resources (whether mineral, vegetable or animal); and human creativity and ingenuity. Capitalism's trick is 
to appropriate these in order to create a profit which can be reinvested to create more commodities, and further profit, in an ongoing (albeit turbulent) process of development. Continuous expansion is thus one of its essential features. The expansion is both an expansion into new areas of human life (exemplified by new commodities that meet demands that were previously met outside the money economy or not at all, for instance new drugs, or new entertainment media), and a spatial expansion - into new parts of the world. Furthermore, it has several different dimensions. The expansion may be driven by the need to seek out new sources of raw materials, ranging from DNA to fossil fuels (Altvater, 2006); to find new markets (Luxemburg, 2003); or to find new places to invest the surplus, or 'sites of accumulation' (Harvey, 2003). It may also be looking for somewhere to dump the detritus resulting from all these other activities. Or, finally, the quest may be for new supplies of labour (Froebel, Heinrichs and Krey, 1977; Huws, 2003). These different drivers are dynamically interconnected with each other. For instance new groups of workers drawn into the production process will also constitute a new market for the commodities produced; investments in new infrastructures will create access to new sources of raw material and open up new sites for production, and so on.

One of the puzzles confronting those who seek to understand the dynamics of capitalist expansion has, for many years, been this: what happens when it runs out of room to expand? In theory, this could happen in relation to any of these dimensions: the world could, for instance, run out of some raw materials; markets could become saturated; we could drown in our own waste; there could be an epidemic of such proportions that the supply of labour dries up; or some other unforeseen catastrophe could take place. Some have speculated that terminal crises of capacity have only been avoided by the destruction of war and the rechannelling of surplus into investments in arms manufacture (Kidron, 1967). This is not the place for a detailed discussion of such extreme eventualities. It is, however, useful to remind ourselves that the scope for expansion is not unlimited and, as fewer and fewer areas of the world's population remain outside the market economy, the pressures increase: pressures to invent new commodities, competitive pressures to make them better or cheaper than anyone else, pressures to reach new consumers and persuade them to buy more, and pressures to do all these things more quickly, because, with the instantaneous access to information created by the internet, the moment in which any given supplier has a market advantage is becoming shorter every day.

In order to understand the place of creative work in all this, it is important to remember that everything we now have, at least everything that is produced within the money economy, whether this is products, processes, infrastructure or 'knowledge', is the result of past creativity. The technical division of labour across an economy is the result of processes of commodification which took place in the past and which continue to evolve. Before the first industrial revolution, for instance, all the functions involved in the production of a piece of cloth might have been carried out, if not by the same person, probably within the same household, including spinning, dyeing, designing, weaving, quality control, marketing, sales and so on. In industrialised fabric production these tasks may be divided not just between different workers but even between different industries, with a complex geographical division of labour. In the process splits have 
taken place between mental and manual tasks: between 'head' and 'hands'. Most of the manual tasks have been automated and routinised; the mental ones have been further divided up into 'executive', 'clerical', 'professional' and 'technical' functions. And some of these would fall into most people's definitions of 'creative': for instance some of the activities involved in the research and development of new fibres and dyes, the design of new fabrics, the invention of creative ways to market them and various ancilliary activities like designing the companies' websites or producing their annual reports. But what is important to remember is that they all have a distant ancestry in the 'craft' of those artisanal textile workers. The same could be said of a myriad other activities.

The sequence of events can be schematically summarised as follows. In the beginning, we have a worker or group of workers carrying out some task that involves the exercise of skill. Following Michael Polanyi (1967) we can describe this skill as 'tacit', a word that describes an ability or facility or knowledge that we have without being able to define precisely what it consists of. Sometimes it may even not be perceived as a skill but as a 'gift' or a 'talent' or inherited aptitude. The possession of this tacit knowledge gives these workers some bargaining power in the labour market; nobody else can do what they do, or at least not as well or as quickly. And, of course, the more they have managed to restrict access to this knowledge (for instance through long apprenticeships, or difficult-to-get qualifications, or membership of hard-to-enter guilds, or the requirement to swear oaths of secrecy), the greater will be their ability to insist on high pay or favourable conditions. For their employers, therefore, they constitute something of an obstacle to rapid expansion.

In order to cheapen production processes, or rapidly expand production (usually, but not necessarily involving the mechanisation or automation of all or parts of the process) this tacit knowledge must be codified, that is, it has to be analysed and broken down into its component parts so that these can be turned into a set of instructions that can be replicated by less-skilled people or a machine (Braverman, 1974). This stage can also be referred to as standardisation. Codification does not necessarily mean simplification. It can result in highly complicated algorithms, models, databases or programmes requiring abstruse knowledge that is only available to a small highly trained group of workers. Nevertheless, codified knowledge is systematised, rational and calculable.

Once tasks have been standardised, they can be counted easily, because each unit in each stage of the process is essentially the same. This makes it possible to specify tasks numerically and to manage workers, not by standing over them and making sure that they are really working, but by measuring their outputs, or standardised 'performance indicators'. And, once these outputs have become measurable, a price can be determined for them. No longer an indefinable part of a bundled-together collection of skills and knowledge, they have become separate, quantifiable entities in a division of labour. ${ }^{3}$ They have become tradeable. And once work can be managed by results, if those results

$3 \quad$ Work that can be managed by results can in principle also be paid by results although this need not necessarily be the case. It is perfectly possible - and indeed most often the case - for a group of workers to be paid by the hour even though the products of their labour are sold individually and their services individually priced by the employer. 
can be readily transported (whether in the form of physical components or of digitised information that can be sent electronically), then there is no longer any need for it to be carried out in the same place, or by the same organisation. This can lead to changes in the division of labour within an organisation (e.g. merging or breaking up traditional structures into separate cost or profit centres, automation of processes, and/or relocating them to other sites) or it can lead to subcontracting them to other organisations. Spatial and contractual restructuring may be combined in many different configurations - for instance a function may be outsourced with a transfer of personnel to an external company, on an adjacent site; it may be relocated in its entirety to another company in another country; it may continue to be carried out on the same site but by employees of a temporary agency or a subcontractor; or it may be carried out by freelancers. A global company may decide to centralise a particular function on a single site in one country or, conversely, to decentralise it to a dispersed network of agents (Flecker \& Kirschenhofer, 2002). The point is that once any task has been reduced to standard components, or modules, these modules can be reconfigured in a huge variety of ways, to suit the particular needs of any given organisation at any particular point in time. The greater the degree of standardisation, the greater the scope for reconfiguration, and the more potentially complex the global division of labour.

This is, of course, a highly schematic overview, but it is one that seems to be applicable to the development of all commodities, whether these are goods or services (Huws, 2003). It is a process which is self-replicating: every time a process becomes standardised, the division of labour becomes more complex; and each time this happens, new processes are required, inorder to develop and manage this new division of labour. Each time, a new split between 'head' and 'hands' takes place, some manual jobs are automated out of existence while others become less skilled and more routine, whilst simultaneously new non-manual jobs are created to manage the machines and the manual workers. Meanwhile, the 'head' jobs are themselves subject to rationalisation and standardisation processes, leading to further sub-divisions. The overall effect is a continuous elaboration of the technical division of labour. In this fracturing, more and more separate steps are involved in the development of any given commodity. If we think of a complex modern commodity like a mobile phone, it becomes apparent that determining what parts of its value have been contributed by what worker would be a task of forensic magnitude - so many fractions of so many standardised processes, so much codified knowledge, extracted from so many workers, living and dead, so many ancillary activities involved in getting it from the germ of an idea to the consumer, are involved.

It is not just new consumer products that are constantly entering the market as a result of these processes. Their production also involves intermediary inputs in the form of other commodities, including the machinery used to produce them, the infrastructure and services required to make them run, and a range of other business services, each of which, to the extent that it is standardised and capable of being traded at a profit, can also be regarded as a commodity, whether this is the provision of accountancy or an outsourced customer service call centre; an insurance policy or website management; logistics services or market research.

So, where do creative workers fit into this picture? First and most obviously we have to point out that, using a broad definition, some measure of creativity can be said to be in- 
volved in just about any tacit process, whether it is recognised as such or not. Often, indeed, an activity is only appreciated as creative when it has already been replaced by more standardised, automated processes. When skills become obsolete, they usually morph very quickly from the taken-for-granted abilities of the lowly tradesperson into 'creative' crafts carried out as educational stimulation for school children, leisure activities for the idle, therapy for the mentally ill or the manufacture of luxury one-off products for sale to the rich. Suddenly, making pottery, embroidery or ornamental ironwork is no longer just the result of training, or patience or a 'knack' but requires 'talent', 'flair' and 'artistry'.

The results of workers' past creativity is thus the raw material for what we already have. But new creativity is constantly needed at every stage in the process described schematically above. It is needed to analyse what is being done tacitly and imagine how this knowledge can be codified and standardised. It is needed to invent the machines that can replicate it and formulate the instructions to run these machines. It is needed to find ways to persuade the old workers to change their ways (or depart peacefully) and to train the new ones. It is needed to devise ways to change the spatial and organisational structures within which work is organised and to manage these, and to make sure that all the separate units are communicating with each other. It is needed to persuade people to buy the products and understand how to use them. It is needed to carry out research and invent new products and processes. It is needed to adapt existing products and processes for new purposes. It is needed to provide content for the exponentially growing (and technologically diversifying) mass media: to educate, entertain and inform the public and cater to their aesthetic and spiritual needs. Finally, it is needed for a number of functions traditionally carried out by government ranging from providing health services to waging war.

The emergence of new forms of creative work does, not, of course mean the death of all the old forms. There remain many spaces in the system for lucky individuals to exercise autonomy and gain huge satisfaction from their work, whether this is making music, designing buildings, making films or writing novels. These spaces are, however, becoming more constrained, because of the increasing dominance of a few giant media conglomerates, the bureacratisation of funding processes, and the sheer pressure of competition.

\section{What does this mean for creative workers?}

Creative workers are in an extraordinarily ambiguous position in all this. They are, on the one hand, agents of change. Without new ideas, the whole system would grind to a halt. The expansionary logic underlying capitalism means that it cannot stand still. Failure to innovate means being overtaken by the competition which means eventual displacement from the market, however good the product. A constant supply of new ideas is therefore absolutely necessary. On the other hand, in the process of innovation, what preceded it is rendered obsolete. Whether it is visible or not to the creative worker (and often it is), the process of creation is therefore also a process of destruction, sometimes the destruction of another worker's livelihood. Mike Hales (1980) described some of the contradictions that arise here from the perspective of a systems analyst whose job is to redesign other people's labour processes. Having to deal with the knowledge that they may have harmed another person's life chances may also do damage to traditional allegiances and solidarities but it is only one of many challenges creative workers face. 
More acute, for many, is the problem of the ownership of their own ideas. Ideas, unlike words, images or music (which can be copyrighted) and designs (which can be patented) do not form part of any regulated market. Whilst being an 'ideas person' may be your greatest asset, the moment you have communicated that idea to someone else it ceases, legally speaking, to be yours. In parting with it, whether to an employer, a potential employer or a client, you are therefore taking the risk that you may not get the credit for it or, indeed, even be rewarded for it at all. Once others have this idea, your usefulness to them may well be at an end. Even if you are an employee and your employer continues to employ you whilst using your idea, this idea might only have a short shelf-life. If it is a good one, the chances are that it will be quickly and widely copied. If it is bad then it is likely to be dropped. Every idea is therefore like a little grenade, with the capability of damaging the person who throws it as well as making an impact where it is thrown. It is a cliché of the creative industries that you are only as good as your last idea, but, especially in precarious labour markets with a rapid turnover in ideas, this is increasingly the reality for many workers.

Ideas are not the only assets of creative workers, of course; they also produce intellectual property in forms that can be legally protected by patents and copyright, as well as possessing abundant knowledge, experience and what has come to be known as 'social capital' (Bourdieu, 1983) - reputations and networks of contacts. But, just like the tacit knowledge of artisanal weavers, these too are subject to appropriation, standardisation and incorporation into new commodities. Creative workers are not only the architects of commodification; they are also its victims.

'Knowledge management' practices explicitly target these workers. They are asked to pool their contacts in common address books; to participate in brainstorming sessions where their ideas are recorded; ${ }^{4}$ to write manuals explaining the programmes they have developed; to run training courses for their junior colleagues or 'mentor' them; to share their 'frequently asked questions'; to participate in the development of standard procedures whose descriptions will be incorporated into quality standards, or even outsourcing contracts for others to abide by; to suggest the 'performance indicators' that will be used to determine their future pay and promotion; to place their work in progress or powerpoint presentations onto corporate or university intranets; and to contribute to the development of 'knowledge databases'.

Two consequences of this development deserve comment here. First, by participating in these practices creative workers are contributing to their own dispensibility. By sharing their knowledge they are cheapening it, and rendering themselves more easily replaceable. However, because they rarely work alone, but are typically working in teams with an internal division of labour, they cannot afford not to share this knowledge. Not only will the quality of the overall product (and hence, perhaps, their personal reputations) be adversely affected if there is poor communication within the team; and not only will they have to do more work if their colleagues don't have the skills to help them out; they also want to learn as well as teach. The exchanges of knowledge that go on within a collaborating group do not just have a synergistic effect in creating a whole that may be greater than

$4 \quad$ Under the guise of 'total quality management' (Feigenbaum, 1951) policies, such brainstorming techniques are also often used to extract productivity-enhancing ideas from manual workers. 
the sum of its parts; they can also generate considerable intrinsic job satisfaction for those involved, as well as adding to the resources they can bring to future work. If the workers are insecure about their future employment (as is often the case when people are working on projects with a fixed term), then considerable tension can be generated between the urge to co-operate and the urge to compete (Meil, 2004).

Second, even if the workers in question have secure jobs and have not participated in a process of explaining themselves out of work, the very process of codifying their knowledge contributes to a change in the quality of their work. As soon as it is embedded in standardised protocols, specified quality standards and performance indicators, the work starts to lose its spontaneity and the workers their autonomy. The very qualities that attracted them to creative work in the first place start to disappear under the weight of daily routines that involve filling in endless time sheets and job sheets, checking boxes to ensure that standard routines have been followed and documenting every step of the work. This presents a challenge for managers. How can they control this volatile workforce without stopping the flow of new ideas? How can they manage the risk that many of these ideas may be duds? How can they generate an impression that they have provided a funky, fun place to work whilst making sure that productivity stays high? At what point does the coop become so confining that the geese stop laying the golden eggs?

But this development also creates enormous dilemmas for creative workers themselves. Starting from an urge to express themselves or create something meaningful or beautiful they want to give their all to the task in hand. But every extra contribution they make may involve a further degree of self-exploitation - in terms of putting in extra time, accepting lower pay or poorer conditions, or handing over their knowledge in ways that may contribute, either directly or indirectly, to constructing new bars for their own cages, or those of others.

At its harshest, the deal they are offered on the labour market can come perilously close to that of the mother brought before Solomon to decide the fate of her baby ${ }^{5}$ : give up the thing you love, the product of your own creation, to someone else, or see it maimed or killed. It is a vivid example of the sort of alienation attributed to proletarian workers by Karl Marx ${ }^{6}$. Whether we should argue that this alienation has now spread to parts of the bourgeoise or that creative workers now form part of the proletariat is a debate that I have taken up elsewhere (Huws, 2003).

The eager young people flocking to enter creative jobs doubtless have a range of different reactions to this situation. Compared with their parents, or their less adventurous schoolmates, many will undoubtedly feel that they have won a better and freer lifestyle. And they may well attribute to personal inadequacy or bad luck some of the negative experiences they have on the labour market. Yet they are intelligent, educated, critical people with a wide knowledge of the world and an overview of the processes they are involved in. They have to

\footnotetext{
$5 \quad$ Bible, 1 Kings 3:16-28,

6 In Chapter 4 of The Holy Family, Karl Marx and Friedrich Engels, say that, 'The propertied class and the class of the proletariat present the same human self-estrangement. But the former class feels at ease and strengthened in this self-estrangement, it recognises estrangement as its own power and has in it the semblance of a human existence. The class of the proletariat feels annihilated in estrangement; it sees in it its own powerlessness and the reality of an inhuman existence. It is, to use an expression of Hegel, in its abasement the indignation at that abasement, an indignation to which it is necessarily driven by the contradiction between its human nature and its condition of life, which is the outright, resolute and comprehensive negation of that nature.' (Marx \& Engels, 1844)
} 
be, because it is precisely for these qualities that they are recruited. Innovation can only come from 'thinking outside the box'. And employers are aware of this. But the imperatives of expansion in a context of competitiveness and rapid change impel them, willy nilly, to embark on precisely those processes that involve putting people into boxes.

What happens in the minds and imaginations of creative people in the process of being inserted into those boxes is terribly important, not just for their own futures but for those of the organisations for which they work and, more generally, for the future of society as a whole. Will they resist and start to bite the hands that feed them? And if they do, will this resistance have any effect? Or will they simply be discarded and replaced by the next wave of starry-eyed youngsters? If they don't actively resist, will they actively co-operate and hasten the commodification process with all the waste and environmental destruction that entails? Will they subside into a cynical semi-acceptance that guarantees them some personal security but does at least offer some passive resistance to the worst excesses of the market? Or will they transfer their energy and originality and idealism to other arenas - outside the boxes - and contribute to the project of imagining and designing alternative social and economic models? The papers in this volume open up a discussion of such questions, as well as giving us a rich descriptive picture of the working lives, attitudes, fears and employment prospects of creative workers.

I will end as I began, giving the last word to William Morris, who was quoted at the beginning of this paper. His utopian future in which all labour is creative and unalienated is contrasted in News from Nowhere with a an old man's recollections of the 19th century, in words which still seem apposite in the 21st.

In the last age of civilisation men had got into a vicious circle in the matter of production of wares. They had reached a wonderful facility of production, and in order to make the most of that facility they had gradually created (or allowed to grow, rather) a most elaborate system of buying and selling, which has been called the World Market; and that World Market, once set a-going, forced them to go on making more and more of these wares, whether they needed them or not. So that while (of course) they could not free themselves from the toil of making real necessities, they created a never-ending series of sham or artificial necessaries [sic], which became, under the iron rule of the aforesaid World Market, of equal importance to them with the real necessaries [sic] which supported life. ... Once they had forced themselves to stagger along under this horrible burden of unnecessary production, it became impossible for them to look upon labour and its results from any other point of view than one - to wit, the ceaseless endeavour to expend the least possible amount of labour on any article made and yet at the same time to make as many articles as possible. To this "cheapening of production", as it was called, everything was sacrificed: the happiness of the workman at his work, nay, his most elementary comfort and bare health, his food, his clothes, his dwelling, his leisure, his amusement, his education - his life, in short - did not weigh a grain of sand in the balance against this dire necessity of "cheap production" of things, a great part of which were not worth producing at all.' (Morris, 1890)

(C) Ursula Huws, 2006 


\section{REFERENCES}

Altvater, E. (2006) 'The social and natural environment of fossil capitalism', Panitch, L. \& C. Leys (eds.) Coming to Terms with Nature, Socialist Register, 2007, London: Merlin:37-59

Barbrook, R. (2006) The Class of the New, London: Openmute

Bontis, N. Assessing knowledge assets: a review of the models used to measure intellectual capital. International Journal of Management Reviews, 2001, Volume 3 No 1, pp 41-60

Bourdieu, P. (1983) 'Forms of capital' in J. C. Richards (ed.) Handbook of Theory and Research for the Sociology of Education, New York: Greenwood Press.

Braverman, H. (1974) Labor and Monopoly Capital: the degradation of work in the twentieth century, New York: Monthly Review Press

Edvinsson, L. \& Malone, M. (1997) Intellectual Capital: Realising Your Company's True Value by Finding its Hidden Brainpower, New York: HarperBusiness

Feigenbaum, A. V. (1951) Quality Control: Principles, Practice, and Administration, New York; London: McGraw-Hill

Flecker, J. \& Kirschenhofer, S. (2002) Jobs on the Move: European case studies in relocating eWork, IES Report 386, Brighton: Institute for Employment Studies

Froebel, F., J. Heinrichs \& O. Krey (1977) The New International Division of Labour, Cambridge: Cambridge University Press

Hales, M. (1980) Living Thinkwork: Where Do Labour Processes Come From?, London: Free Association Books

Hardt, M. \& A. Negri (2000) Empire, Cambridge, MA: Harvard University Press

Harvey, D. (2003) 'The "new" imperialism: accumulation by dispossession', Panitch, L. \& C. Leys (eds.) The New Imperial Challenge, Socialist Register, 2003, London: Merlin:43-63

Huws, U. (2003) The Making of a Cybertariat: Virtual Work in a Real World, New York: Monthly Review Press

Kidron, M. (1967) 'A Permanent Arms Economy', International Socialism No.28, Spring

Lisbon European Council (2000) Presidency Conclusions, 23-24 March, retrieved, November 1, 2006

from http://www.consilium.europa.eu/ueDocs/cms_Data/docs/pressData/en/ec/00100-r1.en0.htm Luxemburg, R. (1913; reprinted 2003) The Accumulation of Capital, London: Routledge (reprint) Marx, K. \& F. Engels (1844) The Holy Family or Critique of Critical Criticism: Against Bruno Bauer and Company. Retrieved on October 30, 2006 from http://www.marxists.org/archive/marx/works/1845/ holy-family/ch04.htm

Meil, P. (2004) 'Spanning the distance: challenges for competency, control and quality of work life', ICT, the Knowledge Society and Changes in Work Workshop, The Hague, 9-10 June

Morris, W. \& E. Belfort Bax (1886) Socialism from the Root Up, Chapter 22: 'Socialism Militant' [Part 1]. Retrieved November 2, 2006 from the William Morris Internet Archive, http://www. marxists.org/archive/morris/works/1888/sru/ch22-1.htm

Morris, W. (1990) News from Nowhere, Chapter 15: 'On the Lack of Incentive to Labour in a Communist Society'. Retrieved, November 2, 2006 from the William Morris Internet Archive, http://www.marxists.org/archive/morris/works/1890/nowhere/chapters/chapter15.htm Polanyi, M. (1967), The Tacit Dimension, Garden City, NY.: Doubleday Sveiby, K. E. (1997), The New Organizational Wealth: Managing and Measuring Knowledge-Based Assets, San Francisco, Ca.: Berret-Koehler

Terkel, S. (1974) Working, Harmondsworth, UK; New York, USA: Penguin

Tiwana, A. (2002), The Knowledge Management Toolkit: Orchestrating IT, Strategy, and Knowledge Platforms (2nd Edition), Upper Saddle River, NJ: Prentice Hall, 2002

Wiener, I.B. (ed) (1990) Journal of Personality Assessment: Vol. 54. Nos. 3 \& 4 